\title{
Septoglomus jasnowskae and Septoglomus turnauae, two new species of arbuscular mycorrhizal fungi (Glomeromycota)
}

\author{
Janusz Blaszkowski • Gerard Chwat • Anna Góralska • \\ Przemyslaw Ryszka $\cdot$ Michail Orfanoudakis
}

Received: 18 January 2014 /Revised: 29 March 2014 / Accepted: 15 April 2014 /Published online: 7 May 2014

(C) The Author(s) 2014. This article is published with open access at Springerlink.com

\begin{abstract}
Phylogenetic analyses of SSU-ITS-LSU nrDNA sequences and morphological studies of spores and mycorrhizae confirmed our supposition of finding two new species of arbuscular mycorrhizal fungi of the genus Septoglomus in the phylum Glomeromycota. Morphologically, the first species, named S. jasnowskae, is distinguished by its pale yellow to brownish yellow, small spores with a 2-layered spore wall, of which the colourless outer layer 1 stains dark in Melzer's reagent and layer 2 is laminate. The spores usually arise in loose clusters. The structures most distinguishing S. turnauae are its two coloured laminate layers in the 4-layered spore wall. In the field S. jasnowskae was associated with roots of Ammophila arenaria and an unrecognized plant species colonizing maritime dunes of the Mediterranean Sea near Thessalonica (Greece) and Calella (Spain), respectively, and S. turnauae formed mycorrhiza with a Cistus sp. (Cistaceae) growing in the soil of a mine located in Sulcis-Iglesiente, SW-Sardinia, Italy. In single-species cultures with Plantago lanceolata as host plant, the mycorrhiza of S. jasnowskae consisted of arbuscules, hyphae and vesicles, and that of $S$. turnauae comprised arbuscules and hyphae only.
\end{abstract}

J. Błaszkowski $(\varangle) \cdot$ G. Chwat $\cdot$ A. Góralska

Department of Ecology and Protection of Environment, West

Pomeranian University of Technology in Szczecin, Słowackiego 17,

71434 Szczecin, Poland

e-mail: janusz.blaszkowski@zut.edu.pl

P. Ryszka

Institute of Environmental Sciences, Jagiellonian University,

Gronostajowa 7, 30-387 Kraków, Poland

\section{Orfanoudakis}

Forest soil lab, Department of Forestry and Management of the Environment and Natural Resources, Democritus University of Thrace, Pandazidou st 193, 68200 Orestiada, Greece
Keywords Arbuscular mycorrhizal fungi · Glomeromycota · Molecular phylogeny $\cdot$ Mycorrhiza $\cdot$ New species

\section{Introduction}

Arbuscular mycorrhizal fungi (AMF) of the phylum Glomeromycota are associated with ca. $70-90 \%$ of land plants (Smith and Read 2008; Brundrett 2009), including those growing in soils highly acidified and contaminated with heavy metals (Bothe et al. 2010) and those colonizing extremely poor maritime sand dunes (Koske 1987; Dalpé 1989; Tadych and Błaszkowski 2000). The fungi frequently increase the supply of nutrients for plants and decrease their sensitivity to different abio- and biotic stresses (Schönbeck 1978; Dehn and Schüepp 1989; Griffioen and Ernst 1989; Smith and Read 2008). Although even low colonization of plant roots by AMG can alleviate such stresses (Pongrac et al. 2009), the effect of influence of AMF may differ, because different species or even strains of a given species of AMF may variously affect plants (Abbott and Robson 1981; Kaldorf et al. 1999; Maherali and Klironomos 2007; Sýkorová et al. 2012). Hence, numerous unsuccessful attempts of application of AMF probably partly resulted from erroneous species identification and the difficult nature of AM fungal taxonomy (Schüßler et al. 2011; Krüger et al. 2012).

To date, ca. 270 species of AMF have been described (Schüßler and Walker 2010), i.e., probably less than $5 \%$ of existing species in the world (Krüger et al. 2009). Of the known species of AMF ca. $62 \%$ produce glomoid spores, i.e., spores similar in mode of formation, spore wall structure and in characters of their subtending hypha to those of Glomus macrocarpum Tul. \& C. Tul., the type species of the genus Glomus Tul. \& C. Tul. (Schüßler and Walker 2010).

Among AMF forming glomoid spores are those of the genus Septoglomus Sieverd., G.A. Silva \& Oehl. Oehl 
et al. (2011) erected this genus from four species originally described as Glomus spp. based on morphological characters of their spores, spore subtending hyphae and ribosomal sequences. All the species produce spores singly or in loose clusters in soil. The spores have a 2-3-layered spore wall and a cylindrical, slightly funnel-shaped or constricted subtending hypha, whose pore is occluded by a septum at the spore base or in some distance from it (Trappe 1977; Trappe et al. 1984; Błaszkowski et al. 2004, 2010; Błaszkowski 2012). Except for S. africanum (Błaszk. \& Kovács) Sieverd. G.A. Siva \& Oehl, whose spores are pale yellow to brownish yellow, spores of the other three Septoglomus spp. are much darker, up to black (Błaszkowski 2012). Spores of the recently described S. altomontanum Palenz., Oehl, Azcón-Aguilar \& G.A. Silva, S. fuscum Błaszk., Chwat, Kovács \& Ryszka, S. furcatum Błaszk., Chwat, Kovács \& Ryszka, S. nakheelum Al-Yahya'ei, Symanczik \& Błaszk. and S. titan B.T. Goto \& G.A. Silva also are dark-coloured (Błaszkowski et al. 2013; Goto et al. 2013; Palenzuela et al. 2013; Symanczik et al. 2014). In all the Septoglomus spp. mentioned above, none of spore wall layers stains in Melzer's reagent.

Redecker et al. (2013) accepted Septoglomus as a genus based on the nrDNA phylogenies, including the phylogeny of S. viscosum (T.H. Nicolson) C. Walker, D. Still \& A. Schüßler, originally described as G. viscosum T.H. Nicolson (Walker et al. 1995) and erroneously transferred to a newly erected monospecific genus, Viscospora Sieverd., Oehl \& G.A. Silva (Oehl et al. 2011). However, S. viscosum spores are hyaline to pale straw (http://invam.caf.wvu.edu/). Redecker et al. (2013) concluded that the morphological features used to erect Septoglomus (Oehl et al. 2011) are symplesiomorphies that can not define monophyletic groups.

We established single-species cultures of two putative undescribed species of Glomeromycota from glomoid spores isolated from trap cultures inoculated with rhizosphere soils and root fragments of three plant species. In the field the first fungal species was associated with roots of Ammophila arenaria (L.) Link and an unrecognized plant species colonizing dunes of the Mediterranean Sea belonging to Greece and Spain, respectively, and the second fungus formed mycorrhiza with a Cistum sp. (Cistaceae) growing in Italy in soil highly acidified and contaminated with heavy metals (Angioloni et al. 2005). Subsequent phylogenetic analyses of sequences spanning the small subunit (SSU, partial) gene, the internal transcribed spacer (ITS1, 5.8S, ITS2, full) and the large subunit (LSU, partial) nrDNA gene, named here SSU-ITSLSU, and morphological studies of spores and mycorrhizae confirmed our supposition and placed both fungi among Septoglomus spp. Consequently. we described below the species as $S$. jasnowskae sp. nov. and S. turnauae sp. nov.

\section{Materials and methods}

Establishment and growth of trap and single-species cultures, extraction of spores and staining of mycorrhizae

Spores examined in this study were derived from both pot trap and single-species cultures. Trap cultures were established to obtain living spores and to initiate sporulation of species that may not have sporulated in the field collections (Stutz and Morton 1996). The method used to establish trap cultures, their growing conditions and the methods of spore extraction and staining of mycorrhizae were as those described previously (Błaszkowski et al. 2012). The growing substrate of trap cultures was the field-collected rhizosphere soil and roots of the plant species sampled mixed with autoclaved coarse grained sand.

Single-species cultures were also established (ten for each species) and grown as given in Błaszkowski et al. (2012). Briefly, the cultures of $S$. jasnowskae (six cultures) were successfully established from small clusters of spores (5-15) attached by a common mycelium, and those of $S$. turnauae (eight cultures) from ca. ten spores. Attempts to establish single-spore cultures failed. The growing substrate of the cultures was autoclaved commercially available coarsegrained sand (grains 1.0-10.0 mm diam-80.50\%; grains 0.1-1.0 mm diam-17.28 \%; grains $<0.1 \mathrm{~mm}$ diam-2.22 \%) mixed $(5: 1, \mathrm{v} / \mathrm{v})$ with clinopthilolite (Zeocem, Bystré, Slovakia) of grains $2.5-5 \mathrm{~mm}$. Clinopthilolite is a crystaline hydrated alumosilicate of alkali metals and alkaline earth metals having, e.g., high ion exchange capability and selectivity, as well as reversible hydration and dehydration. The sandclinopthilolite mixture had a $\mathrm{pH}$ of 7.3. The cultures were kept in transparent plastic bags, $15 \mathrm{~cm}$ wide and $22 \mathrm{~cm}$ high as suggested by Walker and Vestberg (1994). The cultures were watered with tap water once or twice a week, harvested after five months when spores were extracted for study. To reveal mycorrhizal root structures, root fragments located ca. $1-5 \mathrm{~cm}$ below the upper level of the growing medium were cut off with a scalpel. Plantago lanceolata $\mathrm{L}$. was used as host plant in both trap and single-species cultures.

\section{Microscopy and nomenclature}

Morphological features of spores and their wall structure were determined after examination of at least 100 spores mounted in water, lactic acid, polyvinyl alcohol/lactic acid/glycerol (PVLG; Omar et al. 1979) and a mixture of PVLG and Melzer's reagent $(1: 1, \mathrm{v} / \mathrm{v})$. Spores at all developmental stages were mounted in PVLG and PVLG+Malezer's reagent, covered with a cover slip, then crushed to varying degrees by applying pressure to the cover slip and stored at $65^{\circ} \mathrm{C}$ for $24 \mathrm{~h}$ to clear their contents from oil droplets and examined under an Olympus BX 50 compound microscope equipped with 
Nomarski differential interference contrast optics. Microphotographs were recorded on a Sony 3CCD color video camera coupled to the microscope.

Terminology of spore structure is that suggested by Stürmer and Morton (1997) and Walker (1983). Spore colour was examined under a dissecting microscope on fresh specimens immersed in water. Colour names are from Kornerup and Wanscher (1983). Nomenclature of plants is after Mirek et al. (http://info.botany.pl/czek/check.htm), and that of fungi and the authors of fungal names are those presented at the Index Fungorum website http://www. indexfungorum.org/AuthorsOfFungalNames.htm. Voucher specimens were mounted in PVLG and a mixture of PVLG and Melzer's reagent $(1: 1, \mathrm{v} / \mathrm{v})$ on slides and deposited in the Department of Ecology and Protection of Environment (DEPE), West Pomeranian University of Technology in Szczecin, Szczecin, Poland, and in the herbarium at Oregon State University (OSC) in Corvallis, Oregon, USA.

DNA extraction, polymerase chain reaction and DNA sequencing

DNA was extracted from six clusters with four S. jasnowskae spores connected with a common hypha and six single spores of $S$. turnauae as described by Błaszkowski et al. (2013). Spores of each species came from two single-species cultures. The extracts were used as template in polymerase chain reactions (PCR). To obtain the partial SSU, ITS (ITS1, 5.8S and ITS2, full) and the partial LSU nrDNA sequences, here named SSU-ITS-LSU, PCR was performed in a nested procedure with a protocol modified after Krüger et al. (2009) with the SSUmAf-LSUmAr and the SSUmCf-LSUmBr primer pairs for the first and second nested PCR, respectively. The reaction mix in the first PCR contained $10 \mu \mathrm{l}$ of Phusion High-Fidelity DNA polymerase $2 \times$ mastermix (Finnzymes, Espoo, Finland), $1 \mu \mathrm{l}$ each of $10 \mu \mathrm{M}$ SSUmAf and LSUmAr, $2 \mu \mathrm{l}$ of DNA and $6 \mu$ of ultra clean water (Sigma). In the second PCR, the template consisted of $5 \mu \mathrm{l}$ of the product of the first PCR diluted 1:100 with ultra clean water, $10 \mu \mathrm{l}$ of the master mix mentioned above, $1 \mu \mathrm{l}$ each of $10 \mu \mathrm{M}$ SSUmCf and LSUmBr and $3 \mu \mathrm{l}$ of water. Thermal cycling was done in the TPersonal 48-Biometra thermocycler with the following conditions for the first PCR: $5 \mathrm{~min}$ initial denaturation at $99^{\circ} \mathrm{C}, 40$ cycles of $10 \mathrm{~s}$ denaturation at $99^{\circ} \mathrm{C}, 30 \mathrm{~s}$ annealing at $50^{\circ} \mathrm{C}, 60 \mathrm{~s}$ elongation at $72{ }^{\circ} \mathrm{C}$ and $10 \mathrm{~min}$ at $72^{\circ} \mathrm{C}$ for final elongation. The conditions of the nested PCR differed in that the annealing temperature was $53{ }^{\circ} \mathrm{C}$ and the number of cycles was 30 . The PCR products were visualized on $1.0 \%$ agarose gels with $1 \times$ TAE buffer and GelRed ${ }^{\mathrm{TM}}$ Nucleic Acid Gel Stain, $10,000 \times$ in water (Biotium, USA). The PCR products with the expected-size bands were purified with the Wizard ${ }^{\circledR}$ SV Gel and PCR Clean-Up System (Promega, USA) and then cloned with the Zero Blunt TOPO PCR Cloning Kit
(Invitrogen) following the manufacturers' protocols. Eight positive (white) colonies were grown overnight in $2 \mathrm{~mL}$ of LB medium with $50 \mu \mathrm{g} / \mathrm{mL}$ kanamycin at $37{ }^{\circ} \mathrm{C}$ on a horizontal stirrer in a water bath. Plasmids were obtained following the use of QIAGEN QIAprep miniprep kit (Germany). Sequencing of the amplified SSU-ITS-LSU region was performed at LGC Genomics, Berlin, Germany (http://www. lgcgenomics.com/) using M13F and M13R primers. The sequences were deposited in GenBank (KF060318, KF060320-KF060328).

Sequence alignment and phylogenetic analyses

The Glomeromycotan origin of the sequences was initially tested by BLAST (Zhang et al. 2000) search and then their within-species similarity was calculated with BioEdit (Hall 1999). To determine the generic affiliation of our new species, we performed pilot phylogenetic analyses of all their SSUITS-LSU sequences with those representing all recognized genera of Glomeromycota with glomoid spores available in GenBank and published by Krüger et al. (2012). The analyses that generated the phylogenetic tree in Fig. 9 were based on five representative sequences of each our new species and one to five sequences of 20 other species, including the outgroup taxon. Sequences of Sclerocystis sinuosa Gerd. \& B.K. Bakshi and $S$. titan B.T. Goto \& G.A. Silva represented the LSU region only, and the others regarded the SSU-ITS-LSU segment. Of the 76 sequences presented in Fig. 9, 28 were newly obtained by us and all regarded the SSU-ITS-LSU region. Of the new sequences, ten represented the two new species mentioned above, and the others regarded four other AMF described by Błaszkowski et al. (2004, 2010, 2013). This set of sequences was aligned with MAFT v. 7 using the auto option (http://mafft.cbrc.jp/alignment/server/). Bayesian (BI) analysis was performed with MrBayes 3.1 (Huelsenbeck and Ronquist 2001; Ronquist and Huelsenbeck 2003) and Claroideoglomus claroideum (N.C. Schenck \& G.S. Sm.) C. Walker \& A. Schüßler as outgroup, and maximum likelihood (ML) analysis was conducted with PHYML (Guindon and Gascuel 2003). Before the analyses, the best-fit substitution models for the alignment were estimated by the Akaike information criterion (AIC) using Topali v. 2.5 (Milne et al. 2004). In both $\mathrm{BI}$ and ML analyses the model employed was GTR+ G. In the BI analysis the Markov chain was run for 5000000 generations, sampling in every 500 steps, and with a burn-in at 3000. In the ML analysis the transition/transversion ratio for DNA models and the gamma distribution parameter were estimated. Six substitution rate categories were set. Topology and branch lengths and rate parameters were optimized. Support of branches in the ML analysis was estimated in a bootstrap analysis with 1000 replicates. The details of the analyses are available on request. Phylogenetic trees were visualized and edited in MEGA5 (Tamura et al. 2011). 


\section{Results}

Examination of morphological features of spores and mycorrhizae and BI and ML phylogenetic analyses of SSU-ITSLSU nrDNA sequences proved that two AMF found by us in Greece, Spain and Sardinia (Italy) are undescribed species of the genus Septoglomus. The fungi are described below as $S$. jasnowskae sp. nov. and $S$. turnauae sp. nov.

The $S$. jasnowskae sequences (five sequences) were similar in $98.9 \%$, and those of S. turnaum (five) in $99.9 \%$. The alignment used in our phylogenetic analyses was 1692 characters in length, had $1368(80.85 \%)$ phylogenetic informative sites and comprised 76 sequences representing 22 species of AMF. The BI and ML analyses generated trees of identical topologies.

\section{Taxonomy}

Septoglomus jasnowskae Błaszk., Chwat \& Ryszka sp. nov. Figs. 1-8 and 9

MycoBank No. MB 808417

Sporocarps unknown. Spores usually formed in loose clusters, sometimes singly in soil (Figs. 1-6); develop blastically at the tip of, rarely along (intercalary spores) sporogenous hyphae either branched from a parent hypha continuous with a mycorrhizal extraradical hypha (spores in clusters) or directly developed from mycorrhizal extraradical hyphae (single spores). Clusters $470-620 \times 600-1250 \mu \mathrm{m}$ with 2-28 spores (Figs. 1, 2). Spores pale yellow (3A4) to brownish yellow (5C8); globose to subglobose; (39-)59(-98) $\mu \mathrm{m}$ diam; rarely ovoid; $28-42 \times 31-60 \mu \mathrm{m}$; with one subtending hypha (Figs. 1-3, 5, 6). Spore wall consists of two layers (Figs. 1$6)$. Layer 1, forming the spore surface, mucilaginous, hyaline, $(0.8-) 1.2(-2.0) \mu \mathrm{m}$ thick, usually quickly deteriorating with age and frequently completely sloughed in older specimens; in young and freshly matured specimens often swelling and then separating up to $15.5 \mu \mathrm{m}$ from layer 2 in spores mounted in PVLG; sometimes incorporating soil debris and sand grains (Figs. 2-6). Layer 2 laminate, smooth, pale yellow (3A4) to brownish yellow (5C8), (1.3-)2.4(-5.0) $\mu \mathrm{m}$ thick (Figs. 2-6). Only layer 1 stains purplish pink (14A3) to deep Magenta (14E8) in Melzer's reagent (Figs. 4, 5). Subtending hypha pale yellow (3A4) to brownish yellow (5C8); straight or recurved, cylindrical to funnel-shaped, sometimes slightly constricted at the spore base; $(3.3-) 6.8(-11.0) \mu \mathrm{m}$ wide at the spore base (Figs. 2, 3, 5, 6). Wall of subtending hypha pale yellow (3A4) to brownish yellow (5C8); $(1.0-) 1.8(-3.5) \mu \mathrm{m}$ thick at the spore base; continuous with spore wall layers 1 and 2 (Figs. 2, 3, 5, 6). Pore (1.0-)3.3(-6.8) $\mu \mathrm{m}$ diam, open (Fig. 3) or occluded by a curved septum continuous with some innermost laminae of spore wall layer 2 (Fig. 6); septum positioned up to 9.0-14.0 $\mu \mathrm{m}$ below the spore base. Germination unknown.
Figs. 1-8 Septoglomus jasnowskae spores. 2. Intact spores in loose cluster. 2, 3. Swollen spore wall layer (swl) 1 separated from swl2; note swll with incorporated sand grain (sg) and the subtending hypha (sh) with no septum. 4, 5. Intact (4) and highly deteriorated (5) mucilaginous spore wall layer (swl) 1 adherent to laminate swl2; note swl1 and 2 continuous with subtending hyphal wall layers (shwl) 1 and 2. 6 . Subtending hyphal wall layers (shwl) 1 and 2 continuous with spore wall layers (swl) 1 and 2; note the curved septum (s) in the lumen of the subtending hypha. Figs. 7, 8. Mycorrhizal structures of Glomus jasnowskae in roots of Plantago lanceolata stained in $0.1 \%$ trypan blue. 7. Arbuscule (a) with trunk (t) grown from parent hypha (ph). 8 . Vesicle (v), arbuscule (a) with trunk (t) and straight (sih) and Y-branched (Yb) intraradical hyphae. Figs. 1-3, 6-8. In PVLG. Figs. 4, 5. In PVLG+ Melzer's reagent. Figs. $1-8$, differential interference microscopy. Bars: Figs. $1,2=20 \mu \mathrm{m}$, Figs. $3-8=10 \mu \mathrm{m}$

Mycorrhizal associations. In the field S. jasnowskae was associated with roots of $A$. arenaria and an unrecognized plant species growing in maritime dunes of the Mediterranean Sea.

In single-species cultures with $P$. lanceolata as host plant, S. jasnowskae formed mycorrhiza with arbuscules, vesicles and intra- and extraradical hyphae (Figs. 7, 8). Arbuscules were usually widely dispersed along the root fragments examined. They consisted of a short trunk grown from a parent hypha and numerous branches with fine tips (Fig. 7). Vesicles were numerous and usually highly separated from each other. They were ellipsoidal to oblong; 27.0-57.5 ×51.0-154.0 $\mu \mathrm{m}$; when observed in a plan view (Fig. 8). Intraradical hyphae grew along the root axis, were $(2.0-) 5.7(-10.0) \mu \mathrm{m}$ wide, straight or slightly recurved, and occasionally formed $\mathrm{H}$ - or Yshaped branches (Figs. 7, 8) and coils. The coils were ellipsoidal to oblong; $12.0-31.5 \times 45.5-110.0 \mu \mathrm{m}$; when seen in a plan view. Extraradical hyphae were $(2.0-) 3.0(-5.0) \mu \mathrm{m}$ wide and occurred abundantly. All the structures stained intensively blue [pale violet (16A3) to deep violet (16D8)] in 0.1\% trypan blue (Figs. 7, 8).

Phylogenetic position. In both BI and ML trees $S$. jasnowskae sequences grouped in a clade sister to that with $S$. xanthium and the $S$. jasnowskae clade received high values of support (Fig. 9).

Specimens examined. POLAND, Szczecin, under potcultured P. lanceolata, 10 May 2012, Błaszkowski, J., 3333 (HOLOTYPE, DEPE); Błaszkowski, J., 3334-3352 (ISTOTYPES, DEPE) and two slides at OSC.

Etymology. Latin, jasnowskae, in honor of Prof Dr Hab. Janina Jasnowska, Department of Botany and Protection of Nature, West Pomeranian University of Technology in Szczecin, Szczecin, Poland, a long time and distinguished teacher and student of botany.

Distribution and habitat. Spores of S. jasnowskae have so far been found in two trap cultures inoculated with mixtures of the rhizosphere soils and root fragments of $A$. arenaria and an unrecognized plant species colonizing maritime dunes of the Mediterranean Sea near Thessalonica (Greece) and Calella (Spain), respectively. 


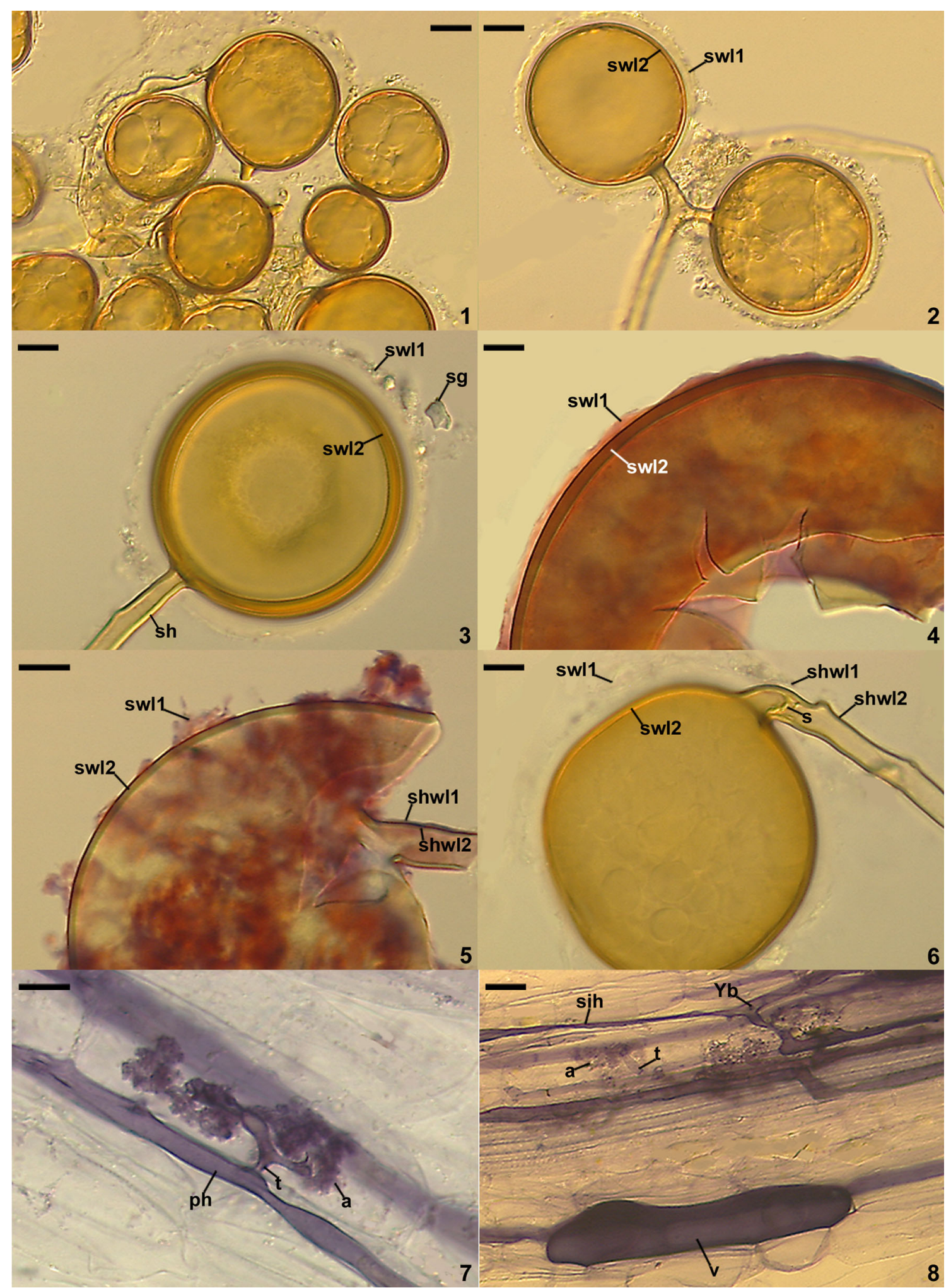

Spores of S. jasnowskae were not found in either ca. 3000 field-collected soils or ca. 2900 pot trap cultures representing different other regions of Europe, as well as Africa, Asia, Cuba, and the U.S.A. (Błaszkowski, pers. observ.).
However, BLAST queries indicated that the $S$. jasnowskae SSU-ITS-LSU sequences we obtained were similar in $99 \%$ to four (FR871359, FR871360, FR871364) LSU sequences of AMF colonizing roots and rhizosphere soils of Brachypodium 
Septoglomus jasnowskae sp. nov. 206-1-2 KF060320

S. jasnowskae 206-1-4 KF060318

$0.98 / 80$ S. jasnowskae 206-2-6 KF060321

S. jasnowskae 206-2-8 KF060322

$0.91 / 72 \sqrt{\text { S. jasnowskae 206-2-3 KF060323 }}$

$1 / 100$ S. xanthium KF154774

S. xanthium KF 154772

$1 / 94$ S. xanthium KF 154773

S. xanthium KF154775

$1 / 100$ S. fuscum KF060316

S. fuscum KFO60315

$1 / 83$ S. fuscum KF060314

S. fuscum KF060317

S. fuscum KFO6O312

$1 / 100$ S. turnauae sp.nov. 243-2-3 KF060326

S. turnauae 243-2-5 KF060328

S. turnauae 243-1-4 KF060324

S. turnauae 243-1-1 KF060327

S. turnauae 243-2-2 KF060325

$1 / 100 \sqrt{\text { S. furcatum KFO60311 }}$

S. furcatum KF060310

1/99 S. furcatum KF060308

-S. furcatum KFO60312

1/100 $\begin{aligned} & \text { S. constrictum FJ461826 } \\ & - \text { S. constrictum FJ461827 } \\ & \text { S. constrictum JF439176 }\end{aligned}$

S. constrictum JF439167

S. africanum KF060305

LS. africanum KF060304

S. africanum KF060306

S. africanum KF060305

S. altomontanum HF674440

S. altomontanum HF674438

$1 / 100$ SS. altomontanum HF674439

S. titan JO312668

$1 / 100$ LS. titan JQ312669

S. titan JQ312667

S. deserticola JQ048857

$1 / 98$

1/100 [S. deserticola JQ048925

S. deserticola JQ048859

S. viscosum KC182036

LS. viscosum KC182037

$1 / 100$ S. viscosum HF548854

S. viscosum HF548853

S. viscosum KC182038

100 Funneliformis caledonius FN547496

\begin{tabular}{|l|l|l}
$0.94 / 75$ & F. caledonius FN547499 \\
\hline F. caledonius FN547494
\end{tabular}

\begin{tabular}{|l|l|l}
$0.94 / 75$ & F. caledonius FN547499 \\
\hline F. caledonius FN547494
\end{tabular}

IF. coronatus FM876794

1876794

Coronatus FM876796

$1 / 89$ F. mosseae FN547474

1/100 F. mosseae FN547476

$1 / 100$ Glomus macrocarpum FR750526

G. macrocarpum FR750530

G. macrocarpum FR750532

G. macrocarpum FR750535

\begin{tabular}{l|l} 
Sclerocystis sinuosa FJ461846 \\
\cline { 2 - 4 } 1/62 Rhizophagus_irregularis FM992377
\end{tabular}

$1 / 62 \sqrt{1 / 100}[R$. irregularis FR750112

LR. irregularis FM865550

R. fasciculatus FR750071

0.5/73 1/100 R. fasciculatus FR750073

R. clarus FM865541

$0.86 / 77$ 1/97 [R. clarus FM865543

R. clarus FM865538

$1 / 100, R$. proliferus FM992390

R. proliferus FM992398

$1 / 79$ R. intraradices FM865606

$1 / 100$ R. intraradices FM865577

$R$. intraradices FM865559

Claroideoglomus claroideum FR750058 
4 Fig. 9 Fifty percent majority rule consensus phylogram inferred from a Bayesian analysis of SSU-ITS-LSU nrDNA sequences of our two new species among 22 known species of AMF, including Claroideoglomus claroideum as outgroup. Sequences of the species obtained by us are followed by their culture numbers (e.g., 206-1) and clone and GenBank accession numbers, respectively. Sequences of the two new species are in boldface. The Bayesian posterior probabilities $\geq 0.50$ and ML bootstrap values $\geq 50 \%$ are shown near the branches, respectively. Bar indicates 0.5 expected change per site per branch

retusum (Pers.) P. Beauv. and Bromus rubens L. growing in semiarid degraded area located in the natural ecological park "Vicente Blanes" in Molina de Segura, Province of Murcia, Southern Spain (Torrecillas et al. 2012), an LSU sequence (JQ287636) of intraradical AMF of Phoenix dactylifera L. growing in the northern territory of the Sultanate of Oman (Symanczik et al. 2014. data) and a SSU-ITS-LSU sequence (JX096589) of an uncultured Glomeromycota from China (unpubl. data). This suggests that $S$. jasnowskae is widely distributed in the world, despite its spores were rarely found in field soils and trap cultures (see above).

Notes. Septoglomus jasnowskae is distinguished morphologically by its pale-coloured, small spores with a 2-layered spore wall, of which the colourless, mucilaginous outer layer 1 stains intensively in Melzer's reagent and the inner layer 2 is laminate (Figs. 1-6). The spores usually occur in loose clusters (Figs. 1, 2). The frequent swelling of spore wall layer 1 in PVLG also is distinctive in the species (Figs. 1-3).

Septoglomus xanthium (Błaszk., Blanke, Renker \& Buscot) G.A. Silva, Oehl \& Sieverd., the closest molecular phylogenetic relative of $S$. jasnowskae (Fig. 9), forms single spores usually closely adhering to roots and frequently intraradical spores (Błaszkowski et al. 2004; Błaszkowski 2012; vs. only hypogeous spores in clusters and single in S. jasnowskae, Figs. 1-3, 5, 6). In addition $S$. xanthium spores are slightly smaller when globose and have a 3-layered spore wall (vs. 2-layered in S. jasnowskae, Figs. 2-6). Spore wall layer 1 of $S$. xanthium is much more persistent and neither swells in PVLG (vs. short-lived and swells in S. jasnowskae) nor stains in Melzer's reagent (vs. stains, Figs. 4, 5). The laminate structural layer 3 of $S$. xanthium is 1.5-2.3-fold thinner than the laminate structural spore wall layer 2 of S. jasnowskae. Finally, the subtending hypha of S. xanthium spores is more regular in shape (cylindrical to flared) and slightly narrower and has a 2.0-2.3-fold thicker wall and a 1.2-2.5-fold narrower pore.

Morphologically $S$. jasnowskae is most similar to G. aureum Oehl \& Sieverd., Claroideoglomus etunicatum (W.N. Becker \& Gerd.) C. Walker \& A. Schüßler and G. pallidum I.R. Hall. These species also produce palecoloured, relatively small glomoid spores with a 2-layered spore wall of which layer 1 stains in Melzer's reagent (Hall 1977; Oehl et al. 2003; Błaszkowski 2012, http://invam.caf.wvu.edu/).
However, G. aureum spores generally are ovoid (vs. globose in $S$. jasnowskae; Fig. 1-3, 6), and when globose they usually are slightly smaller, their spore wall layer 1 does not swell in PVLG (vs. often swells; Figs. 1-3), stains paler in Melzer's reagent and the pore in their subtending hypha is much narrower at the spore base (Oehl et al. 2003; Błaszkowski 2012). In addition G. aureum spores arise only in compact sporocarps, and those of $S$. jasnowskae in loose clusters and singly (Figs. 1-3, 6).

Claroideoglomus etunicatum produces only single spores (vs. spores in clusters and single in S. jasnowskae; Figs. 1-3, 6) that may be much larger, have a structural laminate spore wall layer 2 ca. 2.4-fold thicker and have a subtending hyphae more regular in shape (cylindrical to flared) with a much lighter and thicker wall (Błaszkowski 2012, http://invam.caf. wvu.edu/).

Spores of G. pallidum may occur in epigeous sporocarps (Hall 1977; Błaszkowski 2012; vs. in loose clusters and singly in soil only in $S$. jasnowskae; Figs. 1-3, 6). The spores usually are paler, slightly smaller and their subtending hypha is more regular in shape and hyaline (vs. coloured).

Apart from morphology, the four species compared above also differ in phylogeny. Septoglomus jasnowskae and G. aureum belong in the family Glomeraceae, and C. claroideum represents the family Claroideoglomeraceae C. Walker \& A. Schüssler (Oehl et al. 2003, 2011; Redecker et al. 2013).

Of the Septoglomus spp. known to date, only S. jasnowskae spores show dextrinoid reaction in Melzer's reagent. This is further evidence that membership of a given AMF in the genus Septoglomus may be recognized mainly from phylogenetic analyses of its sequences.

Septoglomus turnauae Błaszk., Chwat \& Ryszka sp. nov.

Figs. 9 and 10-17

MycoBank No. MB 808418

Sporocarps unknown. Spores formed singly in soil (Fig. 10); develop blastically at the tip of sporogenous hyphae continuous with mycorrhizal extraradical hyphae. Spores brownish orange (6C8) to dark brown (9 F8); globose to subglobose; (110-)133(-165) $\mu \mathrm{m}$ diam; rarely ovoid; 115 $135 \times 125-140 \mu \mathrm{m}$; with one subtending hypha (Fig. 10-15). Spore wall consists of four layers (Figs. 11-14). Layer 1, forming the spore surface, evanescent, hyaline, (1.0 $-) 3.1(-5.0) \mu \mathrm{m}$ thick, smooth when intact in youth, usually highly deteriorated or completely sloughed in mature spores (Figs. 11-14). Layer 2 permanent, laminate, smooth, light orange (5A4) to brownish orange (7C8), (2.0-)5.1(-8.8) $\mu \mathrm{m}$ thick (Figs. 11-14). Layer 3 laminate, smooth, light orange (5A4) to brownish orange (7C8), (3.8-)5.6(-9.0) $\mu \mathrm{m}$ thick (Figs. 11-14). Layer 4 semi-flexible, smooth, light orange (5A4) to brownish orange (7C8), $(0.8-) 1.1(-1.4) \mu \mathrm{m}$ thick (Figs. 11-14). None of spore wall layers 1-4 stains in Melzer's reagent (Fig. 12). Subtending hypha brownish orange (6C8) to 

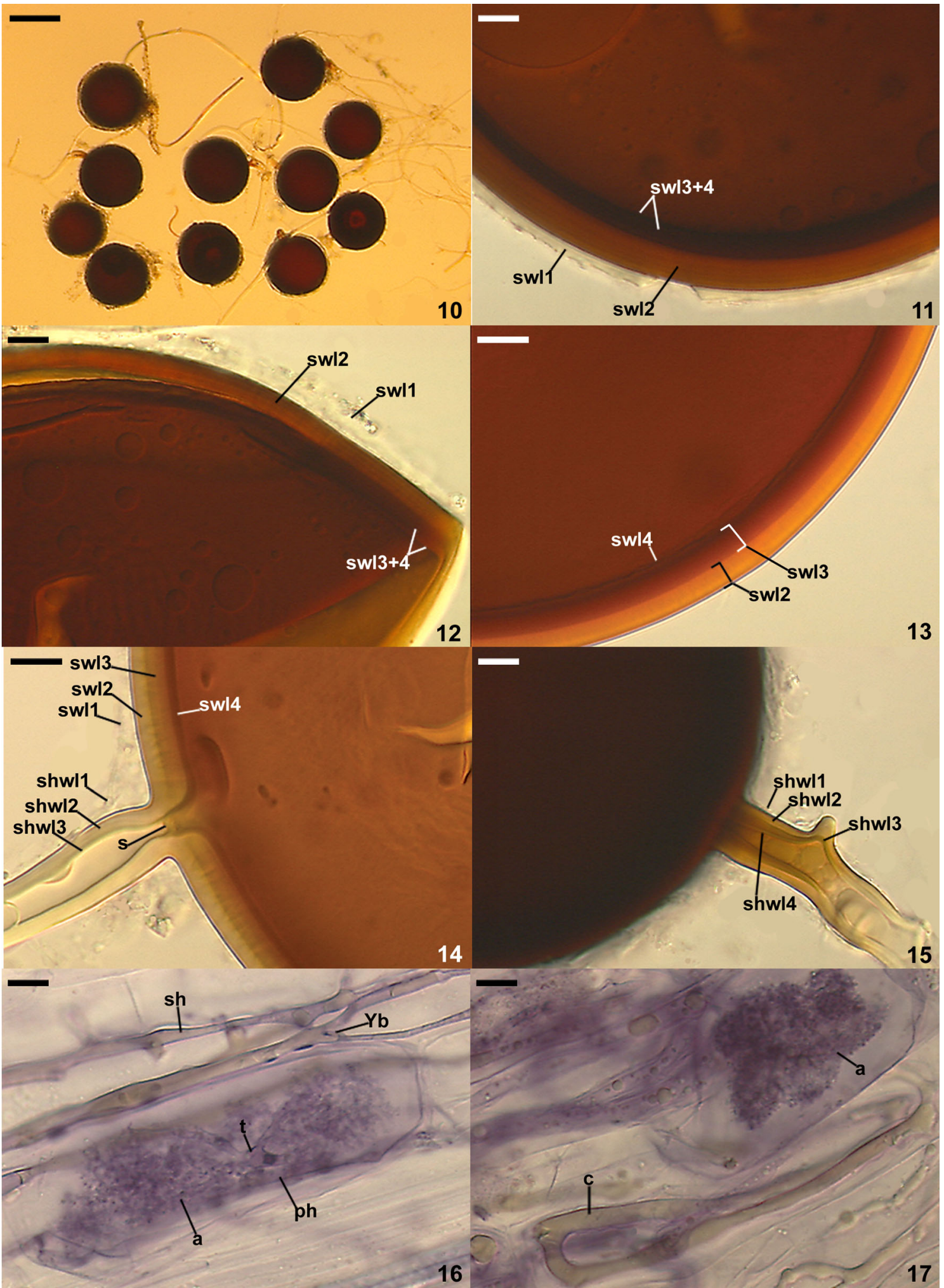

dark brown (9 F8); straight or recurved, usually cylindrical, sometimes slightly funnel-shaped, slightly constricted at the spore base or slightly widening distally; (12.2-)16.7(-21.0) $\mu \mathrm{m}$ wide at the spore base (Figs. 10, 14, 15). Wall of subtending hypha brownish orange (6C8) to dark brown (9 F8); (5.0-)7.7(-11.0) $\mu \mathrm{m}$ thick at the spore base; continuous with spore wall layers $1-3$, when a subtending hyphal pore is closed by a septum (Fig. 14), or $1-4$, when it is open 
4Figs. 10-15 Septoglomus turnauae spores. 10. Intact spores. 11, 12. Spore wall layers 1-4 (swl1-4); swl4 tightly adheres to the lower surface of the dark-coloured swl3 and therefore it is difficult to see. 13. Spore wall layers $2-4$; swll is completely sloughed, and swl4 is slightly separated from swl3. 14. Spore wall layers 1-3 (swl1-3) continuous with subtending hyphal wall layers 1-3 (shwl1-3) and septum (s) in the subtending hyphal lumen continuous with swl4. 15. Wall layers $1-4$ of the subtending hypha with no septum; note shwl4 developing along the inner surface of shwl3. Figs. 16, 17. Mycorrhizal structures of S. turnauae in roots of Plantago lanceolata stained in $0.1 \%$ trypan blue. 16 . Arbuscule (a) with trunk (t) developed from parent hypha (ph) and intraradical straight $(\mathrm{sh})$ and $\mathrm{Y}$-branched $(\mathrm{Yb})$ hyphae. Fig. 10. Spores in lactic acid. Figs. 11, 13-15. Spores in PVLG. Fig. 12. Spore in PVLG+ Melzer's reagent. Figs. 16, 17 Mycorrhizae in PVLG. Figs. 10-17, differential interference microscopy. Bars: Fig. $10=100 \mu$ m, Figs. 3-9= $10 \mu \mathrm{m}$

(Fig. 15). Pore (1.5-)2.2(-3.0) $\mu \mathrm{m}$ diam, narrowing with spore age due to thickening of wall layer 3 of the subtending hypha towards the centre of its lumen and frequently closed by a straight or curved septum continuous with spore wall layer 4 (Fig. 14); septum 1.2-1.5 $\mu \mathrm{m}$ thick, always positioned at the level of spore wall layer 3 (not invaginated into the lumen of the subtending hypha); pore rarely open, when subtending hyphal wall layer 4 develops along the inner surface of subtending hyphal wall layer 3 far below the spore base (Fig. 15). Germination unknown.

Mycorrhizal associations. In the field S. turnauae was associated with roots of a Cistus sp. (Cistaceae).

In single-species cultures with $P$. lanceolata as host plant, S. turnauae formed mycorrhiza with arbuscules and intra- and extraradical hyphae (Figs. 16, 17). No vesicles were found. Arbuscules were numerous and evenly distributed along roots (Figs. 16, 17). Intraradical hyphae were abundant, evenly distributed along the root fragments examined and measured (2.0-)4.3(-6.5) $\mu \mathrm{m}$ wide (Figs. 16, 17). They frequently formed Y-shaped branches and coils, 16.3-20.5 $\times 29.8-$ $103.0 \mu \mathrm{m}$ (Figs. 16, 17). Extraradical hyphae were (1.3 $-) 2.9(-3.6) \mu \mathrm{m}$ wide and occurred abundantly. All the structures stained intensively blue [pale violet (17A3) to deep violet (17E8)] in $0.1 \%$ trypan blue (Figs. 16, 17).

Phylogenetic position. Both BI and ML analyses indicated with strong support values that the closest molecular relative of S. turnauae is S. fuscum Błaszk., Chwat, Kovács \& Ryszka (Fig. 9).

Specimens examined. POLAND, Szczecin, under potcultured P. lanceolata, 10 May 2009, Błaszkowski, J., 3360 (HOLOTYPE, DEPE); Błaszkowski, J., 3361-3370 (ISTOTYPES, DEPE) and two slides at OSC.

Etymology. Latin, turnauae, in honor of Prof Dr Hab. Katarzyna Turnau, Institute of Environmental Sciences, Jagiellonian University, Kraków, Poland, a long time and distinguished student of AMF and arbuscular mycorrhizae.

Distribution and habitat. Spores of S. turnauae were isolated from one pot trap culture inoculated with the rhizosphere soil and root fragments of a Cistus sp. growing in a mine with soil highly acidified and contaminated with heavy metals (Angioloni et al. 2005). This mine is located in SulcisIglesiente, SW-Sardinia, Italy $\left(39^{\circ} 28^{\prime} 51^{\prime \prime} \mathrm{N}, 8^{\circ} 28^{\prime} 51^{\prime \prime} \mathrm{E}\right.$; altitude $384.20 \mathrm{~m}$ ). The soil and roots were collected by $\mathrm{K}$. Turnau on 10 May 2010.

However, our S. turnauae SSU-ITS-LSU sequences were identical in $99 \%$ to three LSU sequences of AMF (FR871355, FR871356, FR871365) obtained via BLAST queries. All represent intraradical and rhizosphere soil AMF of Bra. retusum and $B r$. rubens growing in semiarid degraded area located in the natural ecological park "Vicente Blanes" in Molina de Segura, Province of Murcia, Southeastern Spain (Torrecillas et al. 2012). Thus, S. turnauae probably is widely distributed, at least in Europe.

Notes. The morphological structures most distinguishing S. turnauae are its two coloured laminate layers (layers 2 and 3 ) of the 4-layered spore wall (Figs. 1-8, 9 and 10-14). In a few spores spore wall layer 2 may be difficult to observe, because it is thin and pigmented similarly to spore wall layer 3. However, in most spores spore wall layer 2 almost attains the thickness of spore wall layer 3 , but it is much lighter and thereby well visible (Figs. 12-14).

Phylogenetically, S. turnauae is most closely related to S. fuscum (Fig. 9). However, most S. fuscum spores arise in loose clusters (Błaszkowski et al. 2013; vs. only singly in S. turnauae; Fig. 10). In addition S. fuscum spores usually are lighter, always much smaller, have a 2-layered spore wall (vs. 4-layered in S. turnauae; Figs. 11-14), an over 2-fold wider subtending hypha with a ca. 2.7-fold thinner wall and a pore gradually narrowing due to thickening its layer 2 towards the centre of the subtending hyphal lumen (vs. frequently closed by a septum continuous with spore wall layer 4; Fig. 14).

Intact $S$. turnauae spores observed under a dissecting microscope may appear almost identical in colour and size to those of $S$. altomontanum, S. constrictum (Trappe) Sieverd., G.A. Silva \& Oehl., S. furcatum and S. titan, which are clearly separated phylogenetically from our new species (Fig. 9). These fungi are easy to separate when their crushed spores are examined under a compound microscope. While the spore wall of $S$. turnauae comprises four layers (Figs. 14-14), that of $S$. altomontanum and $S$. constrictum consists of two layers, and the spore wall of $S$. furcatum and $S$. titan is 3-layered (http://www.zor.zut.edu.pl/Glomeromycota/; Trappe 1977; Błaszkowski et al. 2013; Goto et al. 2013; Palenzuela et al. 2013). Septoglomus altomontanum and $S$. constrictum do not differentiate spore wall layers 2 and 4 of $S$. turnauae. Spore wall layer 3 of $S$. titan corresponds with spore wall layer 4 of $S$. turnauae, but $S$. titan lacks spore wall layer 2 of our new species. Spore wall layer 2 of $S$. furcatum is not a permanent structure (vs. permanent in S. turnauae) and is much thinner. In addition spore wall layer 1 of $S$. turnauae is short-lived and 
usually highly deteriorated or completely sloughed in mature spores (Figs. 11-14). In S. altomontanum, S. constrictum, $S$. furcatum and $S$. titan spore wall layer 1 is semi-persistent and frequently remains intact at maturity.

Acknowledgments This study was supported in part by the Polish National Centre of Science, grants no. 2012/05/B/NZ8/00498 and 2012/07/N/NZ8/02363.

Open Access This article is distributed under the terms of the Creative Commons Attribution License which permits any use, distribution, and reproduction in any medium, provided the original author(s) and the source are credited.

\section{References}

Abbott LK, Robson AD (1981) Infectivity and effectiveness of five endomycorrhizal fungi: competition with indigenous fungi in field soils. Aust J Agric Res 32:621-630

Angioloni C, Bacchetta G, Brullo S, Casti M, Galdo GG, Guarino R (2005) The vegetation of mining dumps in SW-Sardinia. Feddes Repertor 116:243-276. doi:10.1002/fedr.200411072

Błaszkowski J (2012) Glomeromycota. W. Szafer Institute of Botany, Polish Academy of Sciences, Kraków

Błaszkowski J, Blanke V, Renker C, Buscot F (2004) Glomus aurantium and G. xanthium, new species in Glomeromycota. Mycotaxon 90:447-467

Błaszkowski J, Kovács GM, Balázs T, Orłowska E, Sadravi M, Wubet T, Buscot F (2010) Glomus africanum and G. iranicum, two new species of arbuscular mycorrhizal fungi (Glomeromycota). Mycologia 102:1450-1462

Błaszkowski J, Kovács GM, Gáspár BK, Balázs TK, Buscot F, Ryszka P (2012) The arbuscular mycorrhizal Paraglomus majewskii sp. nov. represents a new distinct basal lineage in Paraglomeraceae (Glomeromycota). Mycologia 104:148-156. doi:10.3852/10-430

Błaszkowski J, Chwat G, Kovács GM, Gáspár BK, Ryszka P, Orłowska E, Pagano MC, Araújo FS, Wubet T, Buscot F (2013) Septoglomus fuscum and S. furcatum, two new species of arbuscular mycorrhizal fungi (Glomeromycota). Mycologia 105:670-680. doi:10.3852/12-127

Bothe H, Turnau K, Regvar M (2010) The potential role of arbuscular mycorrhizal fungi in protecting endangered plants and habitats. Mycorrhiza 20:445-457

Brundrett MC (2009) Mycorrhizal associations and other means of nutrition of vascular plants: understanding the global diversity of host plants by resolving conflicting information and developing reliable means of diagnosis. Plant Soil 320:37-77

Dalpé Y (1989) Inventaire et repartition de la flore endomycorhizienne de dunes et de rivages maritimes du Quebec, du Nouveau-Brunswick et de la Nouvelle-Ecosse. Naturaliste can (Rev Ecol Syst) 116:219-236

Dehn B, Schüepp H (1989) Influence of VA mycorrhizae on the uptake and distribution of heavy metals in plants. Agric Ecosyst Environ 29:79-83

Goto BT, Araújo AF, Soares ACF, Ferreira AC, Maia LC, Souza CS, Silva GA (2013) Septoglomus titan, a new fungus in the Glomeraceae (Glomeromycetes) from Bahia, Brazil. Mycotaxon 124:101-109

Griffioen WA, Ernst WHO (1989) The role of VA mycorrhiza in the heavy metal tolerance of Agrostis capillaris L. Agric Ecosyst Environ 29:173-177

Guindon S, Gascuel O (2003) A simple, fast, and accurate algorithm to estimate large phylogenies by maximum likelihood. Syst Biol 52 : 696-704

Hall IR (1977) Species and mycorrhizal infections of New Zealand Endogonaceae. Trans Br Mycol Soc 68:341-356
Hall TA (1999) BioEdit: a user-friendly biological sequence alignment editor and analysis program for Windows 95/98/NT. Nucleic Acids Symp Ser 41:95-98

Huelsenbeck JP, Ronquist F (2001) MRBAYES: Bayesian inference of phylogeny. Bioinformatics 17:754-755

Kaldorf MO, Kuhn AJ, Schröder WH, Hildebrandt U, Bothe H (1999) Selective element deposits in maize colonized by a heavy metal tolerance conferring arbuscular mycorrhizal fungus. J Plant Physiol 154:718-728

Kornerup A, Wanscher JH (1983) Methuen handbook of colour, 3rd edn. Eyre Methuen, London

Koske RE (1987) Distribution of VA mycorrhizal fungi along a latitudinal temperature gradient. Mycologia 79:55-68

Krüger M, Stockinger H, Krüger C, Schüßler A (2009) DNAbased species level detection of Glomeromycota: one PCR primer set for all arbuscular mycorrhizal fungi. New Phytol 183:212-223

Krüger M, Krüger C, Walker C, Stockinger H, Schüßler A (2012) Phylogenetic reference data for systematics and phylotaxonomy of arbuscular mycorrhizal fungi from phylum to species level. New Phytol 193:970-984. doi:10.1111/j.1469-8137.2011.03962.x

Maherali H, Klironomos JM (2007) Influence of phylogeny on fungal community assembly and ecosystem functioning. Science 316 : 1746-1748

Milne I, Wright F, Rowe G, Marshal DF, Husmeier McGuire G (2004) TOPALi: sofware for authomatic identification of recombinant sequences within DNA Multiple Alignments. Bioinformatics 20: 1806-1807. doi:10.1093/bioinformatics/bth155

Oehl F, Wiemken A, Sieverding E (2003) Glomus aureum, a new sporocarpic arbuscular mycorrhizal fungal species from European grasslands. J Appl Bot 77:111-115

Oehl F, da Silva GA, Goto BT, Sieverding E (2011) Glomeromycota: three new genera and glomoid species recognized. Mycotaxon 116: $75-120$

Omar MB, Bollan L, Heather WA (1979) A permanent mounting medium for fungi. Bull Br Mycol Soc 13:31-32

Palenzuela J, Azcón-Aguilar C, Barea J-M, da Silva GA, Oehl F (2013) Septoglomus altomontanum, a new arbuscular mycorrhizal fungus from mountainous and alpine areas in Andalucia (southern Spain). IMA Fungus 4(2):243-249

Pongrac P, Sonjak S, Vogel-Mikuš K, Kump P, Nečemer M, Regvar M (2009) Roots of metal hyperaccumulating population of Thlaspi praecox (Brassicaceae) harbour arbuscular mycorrhizal and other fungi under experimental conditions. Int J Phytorem 11:347-359

Redecker D, Schüßler A, Stockinger H, Stürmer SL, Morton JB, Walker C (2013) An evidence-based consensus for the clasification of arbuscular mycorrhizal fungi (Glomeromycota). Mycorrhiza. doi: 10.1007/s00572-013-0486-y

Ronquist F, Huelsenbeck JP (2003) MRBAYES 3: Bayesian phylogenetic inference under mixed models. Bioinformatics 19:1572-1574

Schönbeck F (1978) Einfluss der endotrophen Mykorrhiza auf die Krankheitsresistenz höherer Pflanzen. Z PflKrankh PflSchutz 85: 191-196

Schüßler A, Walker C (2010) The Glomeromycota. A species list with new families and new genera. Schüßler A., Walker C. Gloucester, Published in libraries at Royal Botanic Garden Edinburgh, Kew, Botanische Staatssammlung Munich, and Oregon State University

Schüßler A, Krüger M, Walker C (2011) Revealing natural relationships among arbuscular mycorrhizal fungi: culture line BEG47 represents Diversispora epigaea, not Glomus versiforme. PLoS ONE 6(8): e23333. doi:10.1371/journal.pone.0023333

Smith SE, Read DJ (2008) Mycorrhizal symbiosis, 3rd edn. Academic, San Diego

Stürmer SL, Morton JB (1997) Developmental patterns defining morphological characters in spores of four species in Glomus. Mycologia 89:72-81 
Stutz JC, Morton JB (1996) Successive pot cultures reveal high species richness of arbuscular mycorrhizal fungi in arid ecosystems. Can J Bot 74:1883-1889

Sýkorová Z, Börster B, Zvolenská S, Fehrer J, Gryndler M, Vosátka M, Redecker D (2012) Long-term tracing of Rhizophagus irregularis isolate BEG140 inoculated on Phalaris arundinaceae in a coal mine spoil bank, using mitochondrial large subunit rDNA markers. Mycorrhiza 1:69-80

Symanczik S, Błaszkowski J, Chwat G, Boller T, Wiemken A, AlYahya'ei MN (2014) Three new species of arbuscular mycorrhizal fungi discovered at one location in a desert of Oman: Diversispora omaniana, Septoglomus nakheelum and Rhizophagus arabicus. Mycologia 106(2):243-259. doi:10.3852/106.2.243

Tadych M, Błaszkowski J (2000) Arbuscular fungi and mycorrhizae (Glomales) of the Słowiński National Park, Poland. Mycotaxon 74:463-483

Tamura K, Peterson D, Peterson N, Stecher G, Nei M, Kumar S (2011) MEGA5: molecular evolutionary genetics analysis using maximum likelihood, evolutionary distance, and maximum parsimony methods. Mol Biol Evol 28:2731-2739
Torrecillas E, del Alguacil MM, Roldan A (2012) Differences in the AMF diversity in soil and roots between two annual and perennial gramineous plants co-occurring in a Mediterranean, semiarid degraded area. Plant Soil 354:97-106

Trappe JW (1977) Three new Endogonaceae: Glomus constrictus, Sclerocystis clavispora, and Acaulospora scrobiculata. Mycotaxon 6:359-366

Trappe JW, Bloss E, Menge J (1984) Glomus deserticola sp. nov. Mycotaxon 20:123-127

Walker C (1983) Taxonomic concepts in the Endogonaceae: spore wall characteristics in species descriptions. Mycotaxon 18:443-455

Walker C, Vestberg M (1994) A simple and inexpensive method for producing and maintaining closed pot cultures of arbuscular mycorrhizal fungi. Agric Sci Finl 3:233-240

Walker C, Giovannetti M, Avio L, Citernesi AS, Nicolson TH (1995) A new species forming arbuscular mycorrhizas: Glomus viscosum. Mycol Res 99:1500-1506

Zhang Z, Schwartz S, Wagner L, Miller W (2000) A greedy algorithm for aligning DNA sequences. J Comput Biol 7: 203-214 